\title{
The Influence of the Openness of an E-Learning Situation on Adult Students' Self- Regulation
}

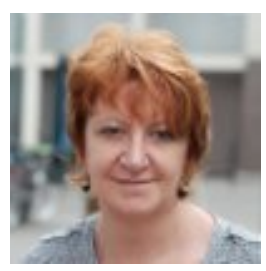

Annie Jézégou

University of Lille 1 Sciences and Technologies, France

\section{Abstract}

This article presents empirical research conducted with French speaking adults studying for a diploma. Their training took place mainly in e-learning. The goal of this research was to identify and explain the processes of influence existing between two specific dimensions: the degree of openness of the components of the e-learning situation and students' self-regulated behaviors in the management of these components. This research was based on the socio-cognitive theory of self-regulation (Bandura, 1986; Schunk \& Zimmerman, 2007; Zimmerman, 2002) and on a theoretical definition of the notion of "openness" (J ézégou, 2005). It applied the "actantial model" (Greimas, 1966; Hiernaux, 1977) for analyzing data collected while using a specific validated instrument of assessment of openness (J ézégou, 2010a). The main results of this empirical work are the role played by three psychological dimensions in the influence processes identified. More empirical study is required to confirm their validity.

Keywords: e-learning; openness; environmental self-regulation; self-regulated behavior; need for autonomy; need for social affiliation 


\section{Introduction}

The emerging French research on self-directed learning assigns a double dimension to the concept of learner self-direction, within a socio-cognitive perspective (Brewer, 2010; Carré, 2003, 2010; Cosnefroy, 2011; Jézégou, 2010b). The first is self-determined motivation (an autonomous, authentic free will to learn) while the second is selfregulation (the exercise of agentic, self-controlled learning activity). The term "double" is used because of an interdependent relationship between these two dimensions (Carré, 2003; Cosnefroy, 2011; Deci \& Ryan, 2000; Schunk \& Zimmerman, 2007). This selfdirection or psychological control is not directly observable. It manifests itself through learner behaviors whose characteristic is to be both self-determined and self-regulated (Carré, 2010; J ézégou, 2010b). Certain environmental factors (educative conditions) may promote or hinder these behaviors (Cosnefroy, 2011; Deci \& Ryan, 2000; Hiemstra, 2000; Vallerand, Carbonneau, \& Lafrenière, 2009; Zimmerman, 2000). The empirical research synthesized in this paper centered only on "environmental self-regulation", one of the three forms of self-regulation in Zimmerman's socio-cognitive model (2002). Its goal was to identify and to explain the influence exercised by the degree of openness of an e-learning situation (environmental factors) on environmental self-regulated behaviors of adult students.

The article first presents the essential features of the theoretical framework linked to the object of this empirical research. It presents the definition of "openness" proposed by Jézégou (2005) and the instrument "GEODE" she constructed to assess the degree of openness of an educative environment (J ézégou, 2010a), notably of e-learning. The main aspects of environmental self-regulation resulting from Zimmerman's work of this specific form of self-regulation in learning are then described, followed by a presentation of the actantial model (Greimas, 1966; Hiernaux, 1977; Piret, Nizet \& Bourgeois, 1996) used for analyzing the data collected from these adult students. The influence of the degree of openness of the components of the e-learning situation on the students' self-regulated behaviors in the management of these components is presented. The possible role of the three psychological dimensions in the influence processes identified is discussed.

\section{Openness and Environmental Self-Regulation: Theoretical Framework}

For nearly 50 years, the theory of self-directed learning has been the subject of much research, following the pioneering works of Houle (1961), Knowles (1975), Long (1975), Tough (1967), Hiemstra (1976) and Guglielmino (1978). In France, a socio-cognitive model of self-directed learning has been gradually elaborated on this basis (Carré, 2003; Carré \& al, 2011). It uses the two key psychological concepts of self-determined motivation and self-regulation to better understand both agentic learning processes and environmental conditions (Carré, 2003; Carré \& Fenouillet, 2009; Cosnefroy, 2011; J ézégou, 2010b). The empirical research presented in this article used this approach in order to elucidate the educative dimensions that are favorable to self-directed learning. 


\section{The Essential Features of the Socio-Cognitive Theory of Self- Regulated Learning}

This socio-cognitive paradigm (Bandura, 1986, 1999) takes the position that human behaviors are not primarily influenced by environmental components, as stipulated in the behaviorist approach or the determinist current in sociology. Nor do they depend solely on internal or personal characteristics as stated in current dispositionalist psychology. According to the socio-cognitive paradigm, behaviors (B) are part of a system of reciprocal causality between personal characteristics (P) and environmental components $(\mathbf{E})$. These three dimensions are subject to reciprocal interactions in variable and contingent importances to conditions, activities and temporalities:

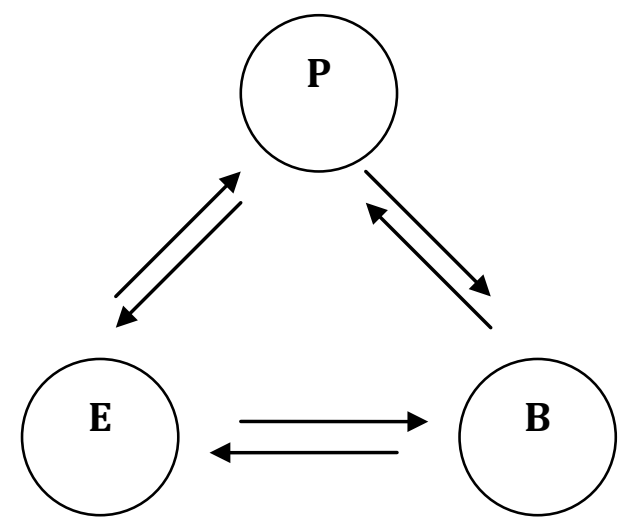

Figure 1. The model of triadic reciprocal causality (Bandura, 1986).

The weight of these three dimensions is not always the same, nor do they necessarily act at the same time. However, the development or the modification of one of them will cause a change in the system of their interactions, as circumstances vary from one individual to another.

The learner's self-regulation follows this triadic reciprocal causality model (Zimmerman, 1989). In its broadest sense, it refers to the control the learner exercises on his or her own cognitive processes by anticipating and preparing procedures, estimating them, and adjusting them according to effects or the observed results (Boekaerts, Pintrich \& Zinger, 2000; Corno, 2001; Cosnefroy, 2011; Schunk \& Zimmerman, 2007; Zimmernan, 2002).

The empirical research synthesized in this paper concerned a specific form of learner self-regulation identified by Zimmerman (2002): "environmental self-regulation". It studied the influence of the degree of openness of the components of a specific elearning situation (environmental dimension) on adult students' self-regulated behaviors in the management of these components (behavior dimension). This can be illustrated as follows. 


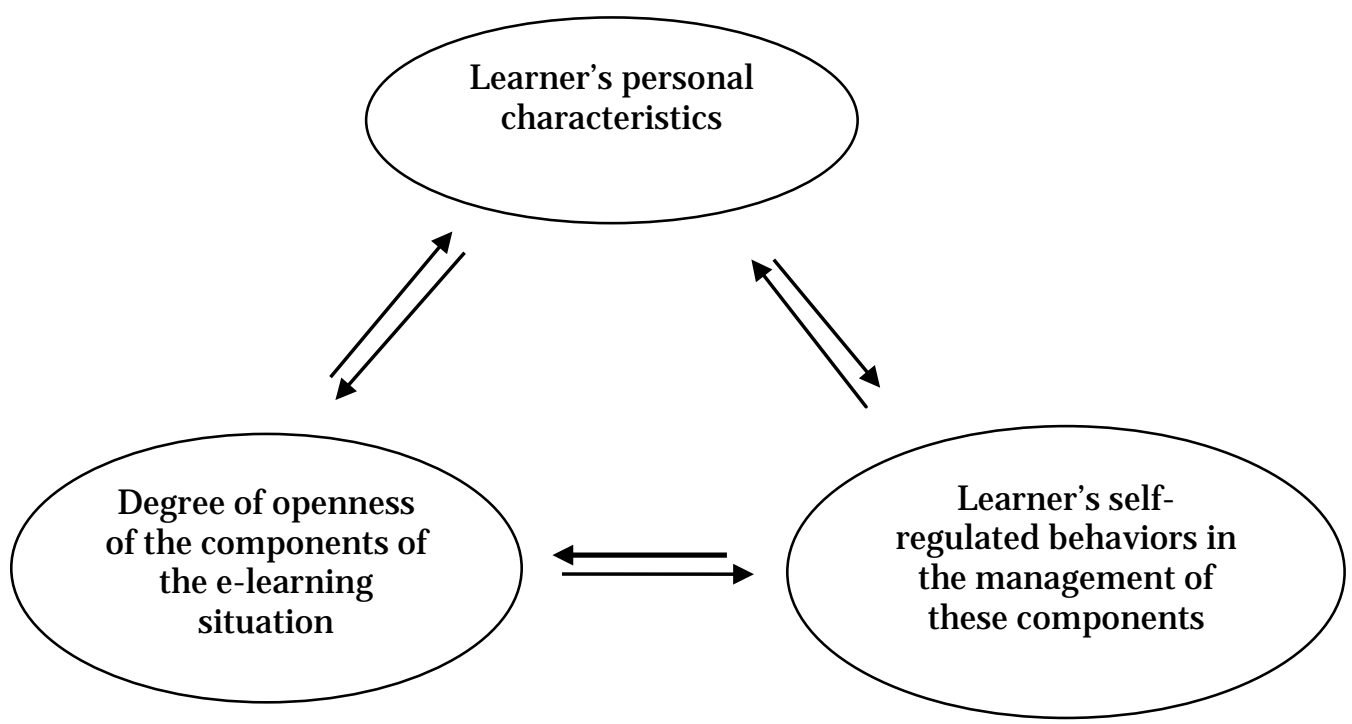

Figure 2. The triadic reciprocal causality model applied to the empirical research presented in this article.

\section{The "Openness" of a Distance Learning Environment: A Definition and a Validated Instrument for Assessment}

The expression "open and distance learning environment" was considered in France as not well-established in theory and was endowed with a fuzzy semantics until the beginning of the 2000s. Such criticism concerned the term open. This term usually referred to opportunities to get access to distance education by digital technologies of information and communication. It was also connected with distance education flexibility mainly impacting spatiotemporal aspects such as timing, place, rhythm of distance learning. Since 2001, several French researchers in education have decided to characterize the essential features of the notion of openness of a distance learning environment (Collectif de Chasseneuil, 2001; Jézégou, 2005). A first definition of openness was proposed by a collective of 14 researchers : "an organized and targeted educational environment which takes account of the learner's uniqueness in his or her individual and collective dimensions, supported by complementary learning situations in terms of places, timing, educational resources, human and technological mediations" (Collectif de Chasseneuil, 2001, p. 177). In proposing this definition, the intention of the collective authors was to move away from engineering concerns centered on technological aspects to thinking of the design of open and distance learning environments as a combination of different modalities, spatiotemporal aspects, tools of communication, and collaboration or human resources. In so doing, it indirectly questioned the educational conditions necessary to promote the expression of the learner's self-direction. 
A further and second French definition answered this question, while providing a theoretical basis for the notion of openness: "openness refers to a set of flexible and empowering educative environments whose main property is to provide freedom of choice to learners so that they can exercise control over their training processes and learning situations" (J ézégou, 2005, p. 103). This definition emphasizes the importance of providing the learner with opportunities for personal decision making (Hiemstra \& Brockett, 1991; Hiemstra, 2000) and self-determination (Deci \& Ryan, 1985) in the choice of various components of the learning situation. GEODE (Grille d'Evaluation de l'Ouverture D'un Environnement éducatif) is a validated French-speaking instrument which assesses the degree of openness of a distance learning environment, notably of elearning (J ézégou, 2010a). It includes a matrix of 14 components where it is possible to provide to learners freedom of choice. These components are regrouped into three categories: (1) spatiotemporal, (2) pedagogical, and (3) the components linked to the educational mediated communication.

Table 1

The Three Categories of GEODE Components (J ézégou, 2010a, p. 89)

\begin{tabular}{|l|l|}
\hline Categories of components & Components \\
\hline Spatiotemporal & access, timing, place, rhythm of learning \\
\hline Pedagogical & $\begin{array}{l}\text { objective, progress, sequence, method, format, } \\
\text { content, evaluation of learning }\end{array}$ \\
\hline $\begin{array}{l}\text { Educational mediated } \\
\text { communication }\end{array}$ & $\begin{array}{l}\text { course documents, tools of } \\
\text { communication/ collaboration, human resources }\end{array}$ \\
\hline
\end{tabular}

GEODE proposes an assessment protocol which includes a data collection method and calculation basis. It enables scoring each of the 14 components and categories, as follows. 
Table 2

The Typology of Openness (J ézégou, 2010a, p. 94)

\begin{tabular}{|c|c|}
\hline Degree of openness (\%) & Typology \\
\hline $100 \geq$ score $>90$ & highly open + \\
\hline $90 \geq$ score $>80$ & highly open \\
\hline $80 \geq$ score $>70$ & highly open - \\
\hline $70 \geq$ score $>60$ & fairly open + \\
\hline $60 \geq$ score $>50$ & fairly open \\
\hline $50 \geq$ score $>40$ & fairly open - \\
\hline $40 \geq$ score $>30$ & barely open + \\
\hline $30 \geq$ score $>20$ & barely open \\
\hline $20 \geq$ score $>10$ & barely open - \\
\hline $10 \geq$ score & closed \\
\hline
\end{tabular}

This instrument was implemented to assess the degree of openness of the 14 components of the e-learning situation in the heart of the empirical research presented in this paper.

\section{Environmental Self-Regulation: Theoretical Grill for Analysis}

Socio-cognitive research on learner self-regulation has mainly developed in North America. In France, it has begun to emerge in recent years (Brewer, 2010; Cosnefroy, 2011; Jézégou, 2008, 2011). Internationally published works place great emphasis on two forms of self-regulation: (1) cover self-regulation, (2) behavioral self-regulation. "Cover" self-regulation is exerted by the learner on his or her emotional, socio-affective, and motivational states. "Behavioral" self-regulation is the learner's control exercised over his or her own learning behaviors. As shown in the Figure 3, Zimmerman (2002) has proposed a third form of self-regulation: environmental self-regulation. 


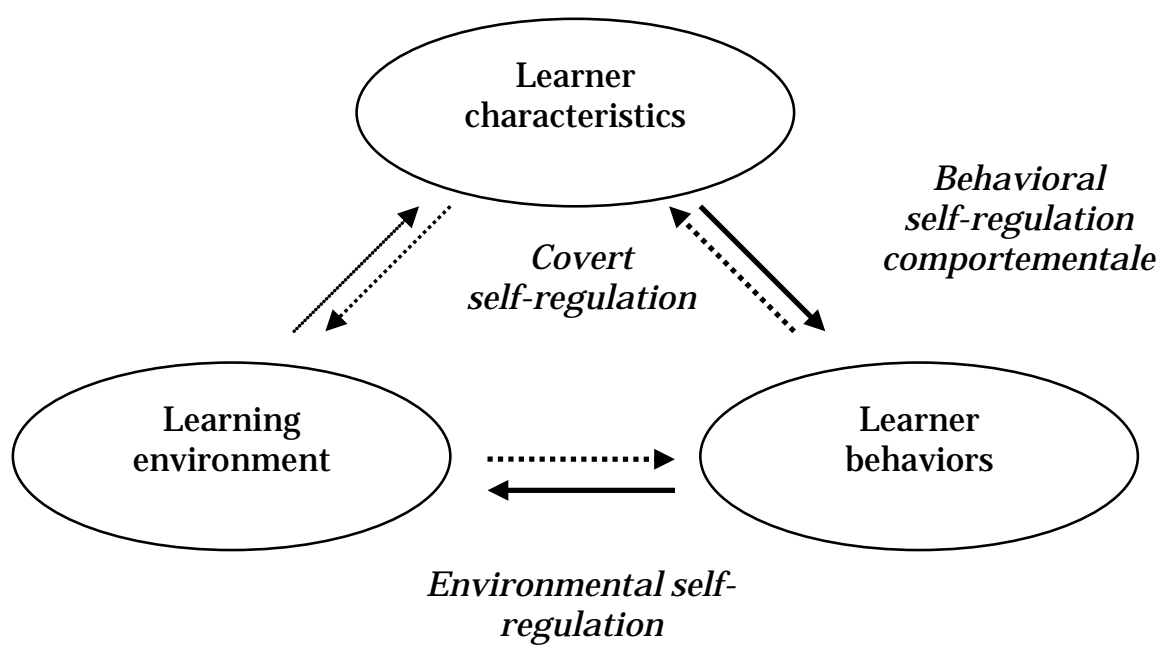



Figure 3. The triadic forms of self-regulation (Zimmerman, 2002, p.71)

Research in the field has tended to neglect this third form of self-regulation. It refers to the control the learner exercises on the management of the various environmental components to create a situation conducive to his or her learning. Although Zimmerman (2002) has identified this third form, he has not made it more explicit. However, he proposes a succinct grill of analysis for environmental self-regulation. In it, environmental self-regulation is considered in two main categories of behaviors. The first category refers to learners' behaviors of adjustment to the formal conditions linked to the different components of the learning situation. These conditions are predetermined and imposed by the designer of the learning situation and/or by the trainer. The second category corresponds to proactive or reactive behaviors in the creation of informal conditions of these components. In proactive self-regulation, the learner chooses his or her goals and elaborates specific action plans, while reactive selfregulation refers to the overcoming of obstacles which hinder the achievement of a goal, by pursuing particular actions. Zimmerman has limited this proposition for the study of self-regulated environmental behaviors (adjusted, proactive, or reactive) to the way the learner manages the three components of place, timing, and human resources. However, a learning situation can not be reduced to so few components. A more detailed analysis has been proposed (J ézégou, 2008, 2011) which suggests studying the way the learner manages the 14 components of GEODE in order to dispose a situation conducive to his or her distance learning. 


\section{The Main Results of the Empirical Research}

The empirical research presented in this article was conducted in 2011 with 27 adults studying for a higher engineering degree at a French research and educational institute (Groupe des Ecoles des Mines). Their training took place mainly in e-learning. These students lived in France and worked in companies, while studying for a higher level of qualification. Nine of them were women. Their mean age was 36 years. A qualitative methodology was used to collect and analyze data, respecting ethical principles of confidentiality and anonymity. The students volunteered for individual web-telephony recorded interviews. The same open-ended questions were asked to all interviewees. These questions notably invited them to express themselves on their objectives and on their specific actions for managing each of the 14 components of the GEODE. The actantial model invented by Greimas in the 1960s was used to analyze the semantic structure of the 27 interviews.

\section{A Qualitative Methodology Based on the Actantial Model}

The actantial model is inspired by French linguistic structuralism originally developed by De Saussure (1913), Merleau-Ponty (1942), and Levi-Strauss (1949). This current of research proposes to interpret and analyze material collected in terms of oppositions, contrasts, and hierarchical structures as they might reflect mental characteristics or organizing principles. The actantial model (Greimas, 1966; 1983; Hiernaux, 1977; Piret, Nizet \& Bourgeois, 1996) enables identification of the structures of meaning that guided perceptions and behaviors by breaking the narrative discourse into seven "actantial roles". The main three are (1) the subject, the narrator of the story; (2) the object, what the subject is directed toward; and (3) the actions undertaken by the subject to reach this objective. Object and actions can be highlighted (positive mode) or depreciated (negative mode) by the narrator. The narrative discourse often contains four additional actantial roles: (4) the helper, helps the subject reach the desired object; (5) the opponent, hinders the subject in his or her progression; (6) the positive receiver, takes advantage of the achievement of the objective and the highlighted actions by the narrator; (7) the negative receiver, takes no advantage of the depreciated action by the narrator. In its fullest form, the "actantial schema" (Piret \& al., 1996) resulting from the analysis can be represented as follows. 




Figure 4. The "actantial schema" in its fullest form (Piret et al., 1996, p. 84).

This method enabled identification of the objectives these adult students had through their self-regulated behaviors in the management of the 14 components of the GEODE, and their specific actions linked to these behaviors were particularly outlined. Comparison of individual actantial schemas showed that the students had common objectives and ways of acting which could be separated into two concomitant phenomena. The first was the adjustment of students to the formal conditions of the temporal and pedagogical components of the e-learning situation. These components had a low degree of openness. The second phenomenon was the creation, by the students, of informal conditions in the management of three components: the format (learning alone or in a group), the digital tools of communication/collaboration (forums, chats, wikis, or email), and the human resources. These components had a high degree of openness.

\section{Low Degree of Openness and Students' Behaviors of Adjustment: Explicative Hypothesis}

The training process was governed by a continuous control of knowledge from individual documents produced by students. The successive deposition of these documents should be carried out in a dedicated space of the e-learning platform, according to a schedule determined in advance by the teachers. This schedule imposed the rhythm of distance learning, according to a sequential logic connected to the module studied in a given period. Each of these modules and sequences corresponded to learning objectives defined in the assessment standards. In addition, they referred to a pedagogical method and course supports pre-determined and imposed by the teachers. These factors explained why the temporal and the pedagogical components (except "the format"), the component of "course documents" of this situation of e-learning, had a low degree of openness. Therefore, they did not offer a choice to students. 


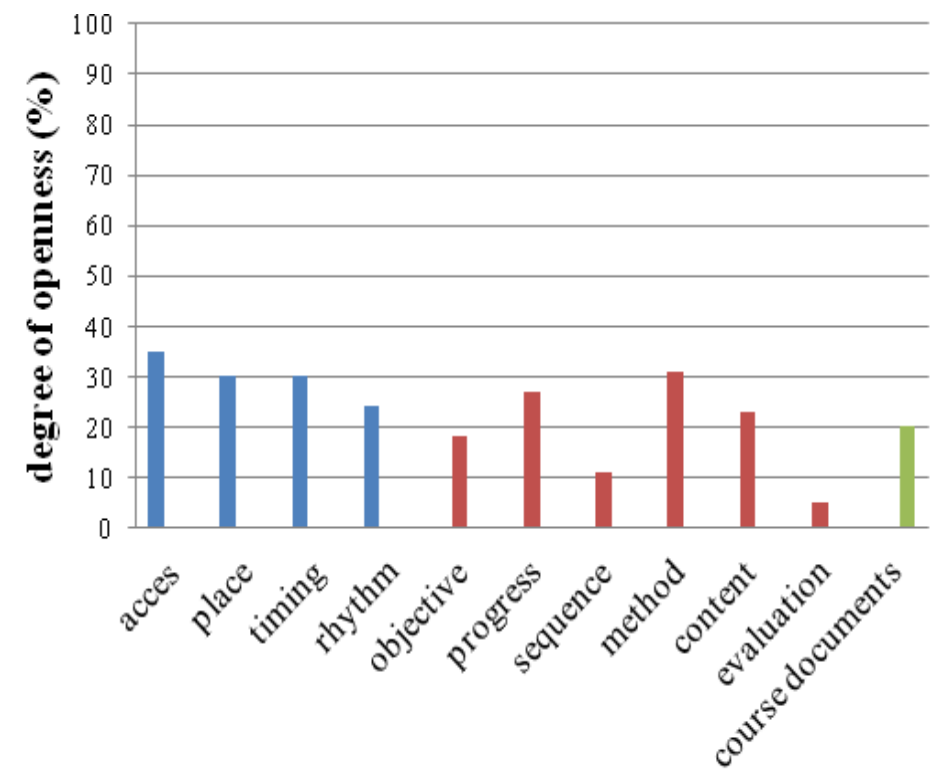

\author{
- spatio-temporal \\ "pedagogical \\ Eeducational \\ mediated \\ communication
}

\title{
Components GEODE
}

Graph 1. The eleven components presented a low degree of openness.

Students perceived the formal conditions linked to these components of their e-learning situation positively. According to them, these temporal and pedagogical conditions, imposed by the teachers, supported their distance learning by "inciting them to work". They interacted with all of these formal conditions by adjusting their behaviors. The following two synthetic meaningful actantial schemas illustrate the logic linked to these adjusted environmental self-regulated behaviors. 
Schedule imposed by

teachers +

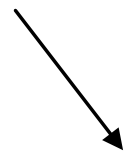

To adjust oneself to the rhythm of distance learning fixed in the schedule +

Student

To set oneself the rhythm of his or her own distance learning -

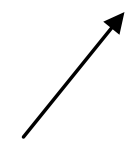

No schedule imposed

by teachers -

Objective, progress,

sequence and method imposed by teachers +

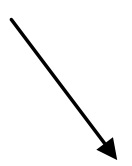

To adjust oneself to the formal conditions linked to these components +

Student

To set oneself
conditions linked to
these components -

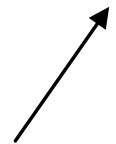

Objective, progress,

sequence and

method not imposed

by teachers -
To oblige oneself to respect the imposed schedule and effectively manage the rhythm of his or her distance learning +

To adopt a random rhythm being subjected to different events and circumstances of his or her professional and personal life -
To satisfy requirements for growing his or her chances to pass the exam +

To fail in the examination and not obtain the diploma -

Figures $5 \& 6$. Two synthetic meaningful actantial schemas illustrated students' adjusted environmental self-regulated behaviors. 
The students intentionally accepted a "dependence state" in order to optimize their chances of graduating. The organismic integration theory offers a hypothesis to explain this phenomenon (Deci \& Ryan, 1990; Gagne \& Deci, 2005): It states that such intentionality involves a process of internalization in which a learner identifies with significant external regulations, assimilating and personally approving them. So, this process could explain the reason why students readily adopted behaviors of adjustment. Thus, although they perceived their e-learning situation as mainly controlled by teachers, they developed a system of interpretation of external control in terms of gains for themselves, accepting and adjusting to the formal conditions of this situation. This hypothesis can be illustrated as follows.



Figure 7. The mediated role of internalization and acceptance by the students of formal conditions linked the eleven components with a low degree of openness.

These behaviors of adjustment were not self-determined. According to the theory of self-determination (Deci \& Ryan, 1985), self-determined behaviors are linked to personal choice of activity in achieving a goal. Concerning the students of this empirical research, their behaviors were mainly influenced by the formal conditions (external factors) linked to the temporal and pedagogical components of their e-learning situation. They could refer to an extrinsic motivation drive by an external regulation (Deci \& Ryan, 1985; Vallerand \& Blanchard, 1998; Vallerand \& al., 2009). The students would adopt adjusted behaviors to obtain a recompense (diploma required), and in order to avoid the failure of not being qualified. The best strategy would be, according to 
them, to adjust to the formal conditions predetermined by the designer or the teacher of the e-learning situation.

\section{A High Degree of Openness and Proactive Self-Regulated. Behaviors: Explicative Hypothesis}

No constraint was imposed on students by teachers in the management of three components: the "format" (to learn alone or in groups), the tools of communication/ collaboration (email, discussion forum, chat), and human resources (teachers, other experts, or peers). These components had a high degree of openness.

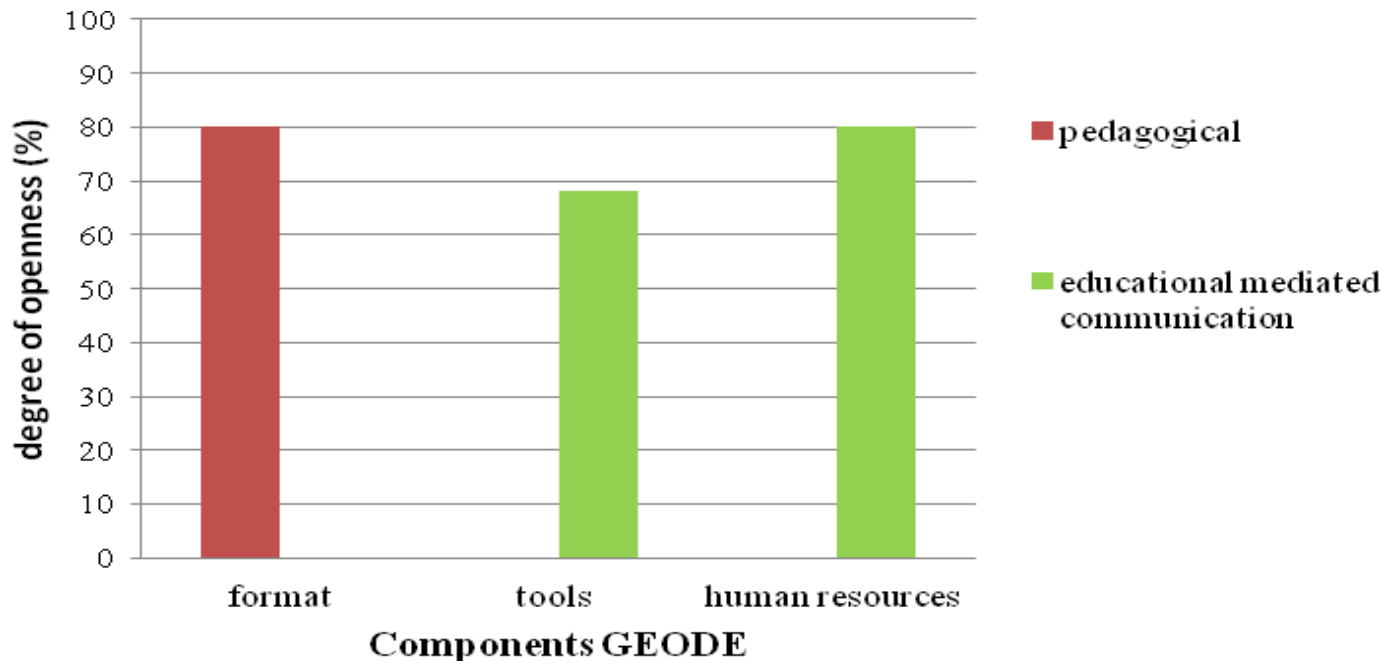

Graph 2. The three components presented a high degree of openness.

Students were free to use the tools available to them on the e-learning platform (essentially a forum of discussion and email) or to request help from teachers or peers. In addition, virtual private classes were also made available on the platform. Teachers did not have access to these classes. Students prioritized the tools that were not subject to control from teachers: their personal email, free web-telephony, or virtual private classes. In addition, they sought help from others in their circle of personal acquaintances (family, friends, or work-colleagues) rather than teachers. The most meaningful result from the analysis of their narrative discourses is illustrated by the actantial schema in Figure 8. 
Freedom to choose format, tools of communication/collaboration and human resources +

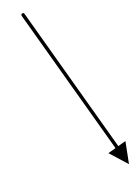

To discuss and collaborate in small groups with other chosen students, using informal tools, without the intervention of the teachers +

Student
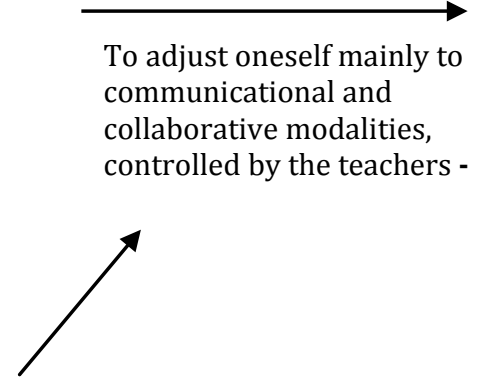

No freedom to choose format, tools of communication/collaboration and human resources -
Other students participating in the group of discussion and collaboration +

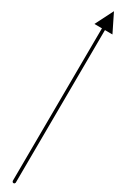

To construct an informal system of mutual aid and support optimizing his or her own individual distance learning to obtain the diploma +

Essentially use the formal system of mutual aid and limiting thus, his or her chances of success to obtain the diploma -

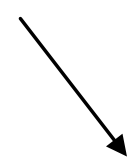

Other students -

Figure 8. Synthetic meaningful actantial schema illustrated students' creative environmental self-regulated behaviors.

Students demonstrated self-regulated behaviors by the creation of informal conditions in the management of these three components. Such behaviors would derive from the co-existence of two processes of influence. 


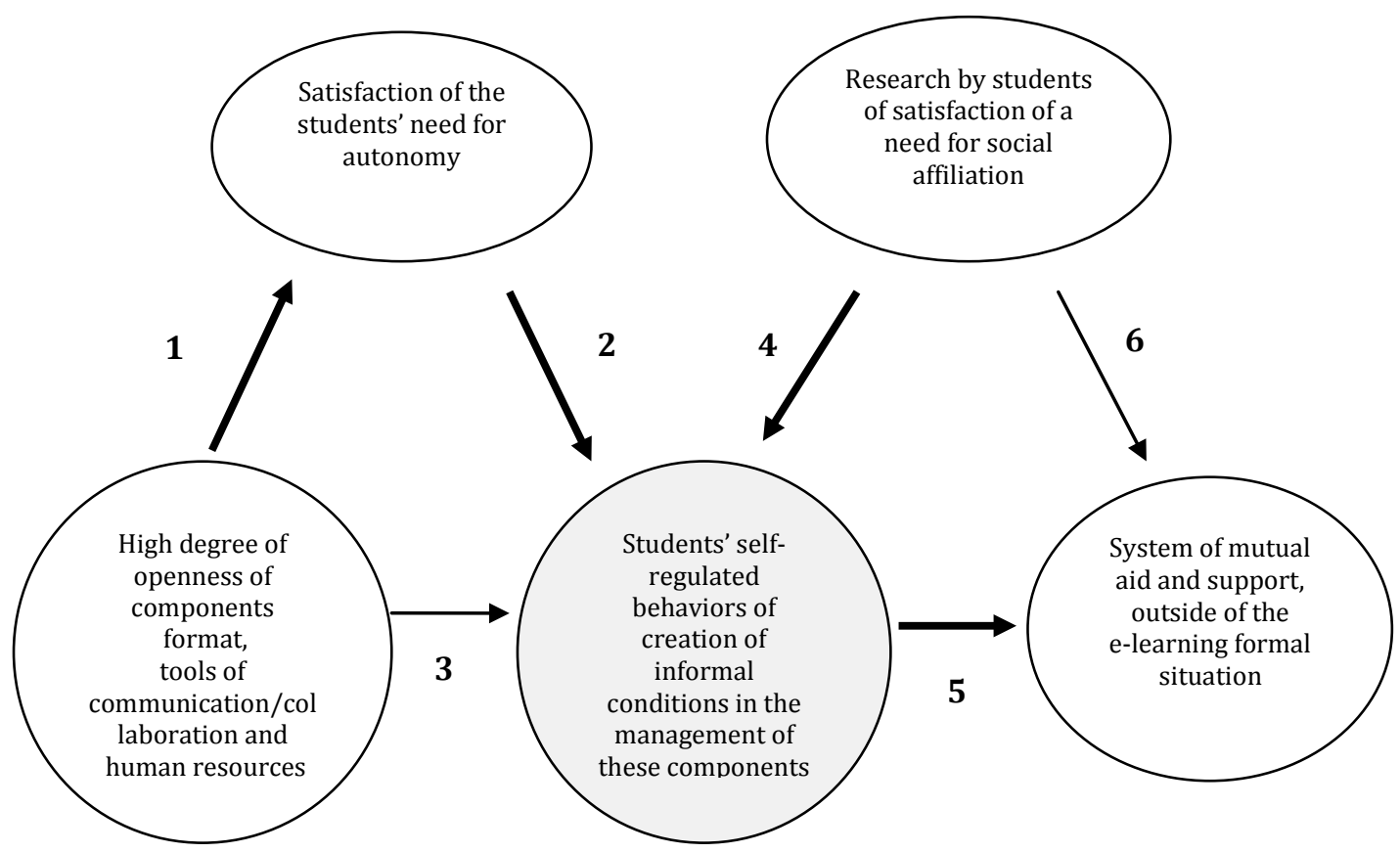

Figure 9. The two influence processes linked to students'self-regulated behaviors of creation of informal conditions in the management of format, tools of communication and human resources.

This figure illustrates a double hypothesis, explaining the students' behaviors. A high degree of openness of these three components is predicted to influence these behaviors by satisfying students'need for autonomy. According to cognitive evaluation theory (Deci \& Ryan, 2000, 2007; Laguardia \& Ryan, 2000; Vallerand et al., 2009), autonomy is a fundamental human psychological need; it occurs in all activities, such as learning. Every human tries to satisfy this need in their interactions with their environment. This need is expressed through the sensation of freedom of choice and action, and also as the author of his or her decisions and acts. Thus, the liberty of choice offered to these students would have contributed to satisfying their need for autonomy and promote these behaviors as the informal conditions of these three components were created. These behaviors would have enabled them to build a system of mutual aid and support, outside the formal situation of e-learning and beyond the pedagogical control of the teachers, mainly by using the private virtual classes. Simultaneously, these behaviors were also motivated by the search for satisfaction of a need for social affiliation. This need is expressed by the feeling of being interconnected, belonging to a community, while being useful to others and taking profit for oneself (Deci \& Ryan, 2000, 2007; Laguardia \& Ryan, 2000, Vallerand \& al, 2009). According to the cognitive evaluation 
theory, this psychological need is also fundamental and universal. Students would have tried to fill it by building a system of mutual aid and support.

This double hypothesis would show that these students were capable not only of grasping the liberties of choice offered to them by the teachers, but also of creating, individually and collectively, the informal conditions that develop a situation conducive to their distance learning. These self-regulated behaviors would be both self-determined and proactive. Indeed, according to the cognitive evaluation theory (Deci \& Ryan, 2000, 2007; Laguardia \& Ryan, 2000; Vallerand \& al, 2009), satisfaction of the needs for autonomy and for social affiliation facilitates self-determined behaviors. The situational motivation linked to these behaviors would be extrinsic in identified regulation (Deci \& Ryan, 1985): The students considered themselves as autonomous when implementing their own decisions; they valued them and considered them significant for attaining their goal, thus optimizing the success of their individual distance learning. These behaviors were also proactive: The students were focused on a goal as they developed actions to enhance their distance learning.

\section{Conclusion}

The coexistence of adjusted and proactive self-regulated behaviors allowed students to reach their purpose: to be successful in their distance learning and to obtain the diploma. On one hand, they adjusted to the formal conditions of the temporal and pedagogical components, such as those imposed by their teachers, in this way ensuring the success of their distance learning. On the other hand, they grasped some of the liberties of choice offered to them by the teachers in order to create the informal conditions of their e-learning situation, these conditions also participating in their project. The existence of these two joint phenomena needs to be verified with other groups of students participating in similar e-learning situations. Thus, the explicative hypothesis proposed on the role of three psychological dimensions in the influence processes identified also could be tested by future empirical research. 


\section{References}

Bandura, A. (1986). Social foundations of thought and action: A social cognitive theory. Englewood Cliffs: Prentice - Hall.

Bandura, A. (1999). Social cognitive theory of personality. In L. A Pervin \& O.P. John (Eds.), Handbook of personality. Guilford.

Boekaerts, P. R., Pintrich, P.R., \&Zeidner, M. (Eds.) (2000). Handbook of selfregulation. London: Academic Press.

Brewer, S. S. (2009). Articuler dispositions des apprenants et dispositifs de formation : Perspectives d'un linguiste en éducation. Dans G. Lameul, A. J ézégou \& A. F. Tollat (dir), Articuler dispositifs de formation et dispositions des apprenants (pp. 45 - 70). Lyon: Chronique Sociale.

Carré, P. (2003). La double dimension de l'apprentissage autodirigé : contribution à une théorie du sujet social apprenant. Revue Canadienne pour l'Etude de l'Education des Adultes, 17-23.

Carré, P., \& Fenouillet, F. (2009). (dir), Traité de psychologie de la motivation. Paris: Dunod.

Carré, P. (2010). L'autodirection des apprentissages. Perspectives psycho-pédagogiques. Dans P. Carré, A. Moisan, \&D. Poisson (dir), L'autoformation, perspectives et recherches (pp. 117 - 169). Paris: PUF.

Carré, P., J ézégou, A., Kaplan, J ., Cyrot, P., \& Denoyel N. (2011). “L’autoformation”. The state of research on self-directed learning in France. International J ournal of Self-Directed Learning, 8(1), 7 - 17.

Collectif de Chasseneuil. (2001). Accompagner les formations ouvertes. Paris: L'Harmattan.

Collectif du Moulin. (2002). Intégrer les formations ouvertes. Paris : L’Harmattan.

Corno, L. (2001). Volitional aspects of self-regulated learning. In B. Zimmerman \& D. Schunk (Eds), Self-regulated learning and academic achievement (pp. 191 225). Mahwah : Lawrence Erlbaum.

Cosnefroy, L. (2011). L’apprentissage autorégulé : Entre cognition et motivation. Grenoble: PUG.

Deci, E., \& Ryan, R. (1985). Intrinsic motivation and self-determination in human behavior. New York : Plenum. 
Deci, E., \& Ryan, R. (1990). A motivational approach to self: Intregation in personality. In Dienstbier (Ed), Perspectives on motivation (pp. 237- 288). Lincoln: University of Nebraska Press.

Deci, E., \& Ryan, R. (2000). The "what" and "why" of goal pursuits: Human needs and the self-determination of behaviour. Psychological Inquiry, 11, 227 - 268.

Deci, E., \& Ryan, R. (2007). Favoriser la motivation optimale et la sante mentale dans les divers milieux de vie. Canadian Psychology, 49, 24 - 34.

De Saussure, F. (1913). Cours de linguistique générale. Paris: Payot.

Fenouillet, F. (2009). Vers une approche intégrative des théories de la motivation. Dans P. Carré, \& F. Fenouillet (dir), Traité de psychologie de la motivation (pp. 305338). Paris: Dunod..

Gagne, M., \&Deci, E. (2005). Self-determination theory and work motivation. J ournal of Organizational Behavior, 26, 331-362.

Greimas, A.J. (1966). Sémantique structurale. Paris : Presses Universitaires de France.

Greimas, A.J . (1983). Du sens : Essais sémiotiques. Paris :Seuil.

Guglielmino, L. M. (1978). Development of the self-directed learning readiness scale. Dissertation Abstracts International, 38, 6467A.

Hiernaux, J . P. (1977). L'institution culturelle. Méthode de description structurale. Paris: PUF.

Hiemstra, R. (1976). Lifelong learning. Lincoln, NE: Professional Educators Publications.

Hiemstra, R., \& Brockett, R. (1991). Self-direction in adult learning: Perspectives, theory, research and practice. New-York : Routledge.

Hiemstra, R. (2000). Self directed learning: The personal responsibility model. In G. Straka (Ed), Conceptions of self-directed learning: Theoretical and conceptional considerations (pp. 93 - 108). Berlin : Waxmann.

Houle, C. O. (1961). The inquiring mind. Madison: University of Wisconsin Press.

Jézégou, A. (2005). Formations ouvertes : Libertés de choix et autodirection de l'apprenant. Paris : L'Harmattan.

J ézégou, A. (2008). Formations ouvertes et autodirection de l'apprenant. Savoirs, Revue Internationale de Recherches en Education et Formation d'Adultes, 16, 97-115. 
J ézégou, A. (2010a). Le dispositif GEODE pour évaluer l'ouverture d'un environnement éducatif. Revue del'Education à Distance / J ournal of Distance Education, 24(2), 83-108. Retrieved from http:// www.jofde.ca/index.php/jde/article/view/ 625

J ézégou, A. (2010b). Diriger par soi-même sa formation et ses apprentissages. Dans B. Raucent \& C.Verazt (dir), Accompagner les étudiants (pp. 53 - 85). Bruxelles : De Boëck Université.

J ézégou, A. (2011). Se former à distance : Regard sur les stratégies d'autorégulation environnementale d'étudiants adultes. Savoirs, Revue Internationale des Recherches en Education et Formation d'Adultes, 24, 79 - 99.

Knowles, M. (1975). Self-directed learning: A guide for learners and teachers. New York : Association Press.

Laguardia, J ., \& Ryan, R. (2000). Buts personnels, besoins psychologiques fondamentaux et bien être : Théorie de l'autodétermination et application. Revue Québécoise de Psychologie, 21(2), 281 - 303.

Laguardia, J ., \& Ryan, R. (2000). Buts personnels, besoins psychologiques fondamentaux et bien être théorie de l'autodetermination et application. Revue Québécoise de Psychologie, 21(2), 281 - 303.

Levi-Strauss, C. (1949). Structure élémentaire de la pensée. Paris: PUF.

Long, H. B. (1975). Independent study in the education of colonial adults. J ournal of Research and Development in Education, 8, 54-65.

Merleau-Ponty, M. (1942). La structure du comportement. Paris : PUF.

Piret, A., Nizet, J ., \& Bourgeois, E. (1996). L’analyse structurale. Une méthode d'analyse de contenu pour les sciences humaines. Bruxelles: De Boëck Université.

Schunk, D.H., \&Zimmerman, B. (Eds). (2007). Motivation and self-regulated learning. New York: Lawrence Erlbaum Associates Inc

Tough, A. M. (1967). Learning without a teacher. A study of tasks and assistance during adult self-teaching projects. Toronto: Ontario Institute for Studies in Education.

Vallerand, J . R., \& Blanchard, C. (1998). Education permanente et motivation : Contribution du modèle hiérarchique de la motivation intrinsèque et extrinsèque. Education Permanente, 136, 15 - 36. 
Vallerand, J . R., Carbonneau, N., \& Lafrenière, M.C. (2009). La théorie de l'autodétermination et le modèle hiérarchique de la motivation intrinsèque et extrinsèque. Dans P. Carré \& F. Fenouillet (dir), Traité de psychologie de la motivation (pp. 47-66). Paris: Dunod.

Zimmerman, B. (1989). A social cognitive view of self-regulated academic learning. J ournal of Educational Psychology, 81(3), 329-339.

Zimmerman, B. (2000). Des apprenants autonomes : Autorégulation des apprentissages. Bruxelles: De Boeck.

Zimmerman, B. (2002). Efficacité perçue et autorégulation des apprentissages durant les études : une vision cyclique. Dans P. Carré \& A. Moisan (dir), La formation autodirigée. Aspects psychologiques et pédagogiques (pp. 69 - 88). Paris : l'Harmattan..

\section{Athabasca University $\mathbf{Z}$}

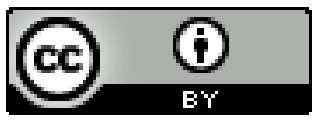

